\title{
PERBEDAAN KARAKTERISTIK USIA, ASUPAN MAKANAN, AKTIVITAS FISIK, TINGKAT SOSIAL EKONOMI DAN PENGETAHUAN GIZI PADA WANITA DEWASA DENGAN KELEBIHAN BERAT BADAN ANTARA DI DESA DAN KOTA
}

\author{
Indira Saraswati, Fillah Fithra Dieny ${ }^{*}$ \\ Program Studi Ilmu Gizi Fakultas Kedokteran Universitas Diponegoro \\ Jl.Dr.Sutomo No.14, Semarang, Telp (024) 8453708, Email : gizifk@undip.ac.id
}

\begin{abstract}
Background : The incident of obesity getting transition not only happened in urban (18,7\%), but also in rural (12\%). Demography transition caused differences characteristics of obesity. The purpose of this study was to determine the differences characteristics of age, food intake, physical activity, socio-economic level and nutritional's knowledge in adult women with overweight between rural and urban.

Method: The design of this study was cross-sectional with consecutive sampling method. Total sample 30 people in each group included overweight women with BMI $>25,0 \mathrm{~kg} / \mathrm{m}^{2}$. Data included characteristics of subject, food intake, physical activity, socio-economic level and nutritional's knowledge that were collected using a questionnaires. Data were analyzed using Independent t-Test and Mann Whitney.

Result : Prevalence of obesity in urban was higher than rural. Most of overweight women in rural and urban was 30-40 years, but the proportion in rural higher than urban. The average of energy, carbohydrate, protein and fat intake in urban was higher than rural. Whereas the average of fiber intake in rural was higher than urban. Physical activity in rural was higher than urban. Income, education and nutritionals knowledge in urban was higher than rural.

Conclusion : The incident of obesity in urban was higher than rural. There were differences characteristics in overweight women between rural and urban include age, intake of energy, carbohydrate, protein, fat, fiber, physical activity, income, education and nutritional's knowledge.
\end{abstract}

Keywords : Age; food intake; physical activity; socio-economic level; nutritional's knowledge; overweight; rural; urban

\section{ABSTRAK}

Latar Belakang : Kejadian obesitas mengalami pergeseran tidak hanya terjadi di perkotaan (18,7\%), namun juga di pedesaan (12\%). Adanya pergeseran demografi menyebabkan perbedaan karakteristik penyebab terjadinya obesitas. Penelitian ini bertujuan untuk mengetahui perbedaan karakteristik usia, asupan makanan, aktivitas fisik, tingkat sosial ekonomi dan pengetahuan gizi pada wanita dewasa dengan kelebihan berat badan antara di desa dan kota.

Metode : Rancangan penelitian ini adalah cross-sectional dengan consecutive sampling. Jumlah sampel masingmasing kelompok 30 orang meliputi wanita dengan kelebihan berat badan dengan IMT >25,0 kg/m ${ }^{2}$. Data meliputi karakteristik subjek, asupan makanan, aktivitas fisik, tingkat sosial ekonomi dan pengetahuan gizi yang diperoleh dari kuesioner. Analisis data menggunakan Independent t-Test dan Mann Whitney.

Hasil : Prevalensi obesitas di kota lebih tinggi daripada di desa. Wanita dengan kelebihan berat badan di desa dan kota sebagian besar berusia 30-40 tahun, namun proporsinya lebih tinggi di desa dibandingkan di kota. Rerata asupan energi, karbohidrat, protein dan lemak di kota lebih tinggi dibandingkan di desa. Sedangkan rerata asupan serat di desa lebih tinggi dibandingkan di kota. Aktivitas fisik di desa lebih tinggi dibandingkan di kota. Pendapatan, pendidikan dan pengetahuan gizi di kota lebih tinggi dibandingkan di desa.

Kesimpulan : Kejadian obesitas di kota lebih tinggi daripada di desa. Ditemukan perbedaan karakteristik pada wanita dengan kelebihan berat badan antara di desa dan kota meliptui usia, asupan energi, karbohidrat, protein, lemak, serat, aktivitas fisik, pendapatan, pendidikan dan pengetahuan gizi.

Kata Kunci : Usia; asupan makanan,; aktivitas fisik; tingkat sosial ekonomi; pengetahuan gizi kelebihan berat badan; desa; kota

\section{PENDAHULUAN}

Globalisasi telah memberikan berbagai dampak kepada masyarakat, dampak negatif yang terjadi adalah perubahan dalam gaya hidup.
Masyarakat mulai beralih dari pola traditional lifestyle menjadi sedentary lifestyle yaitu kehidupan dengan aktivitas fisik kurang dan penyimpangan pola makan dimana asupan 
cenderung tinggi energi (karbohidrat, lemak dan protein) namun rendah serat. ${ }^{1}$ Faktor-faktor tersebut berkaitan dengan risiko kelebihan berat badan (overweight) dan kejadian obesitas.

The World Health Organization memperkirakan sekitar 1 milyar individu mengalami overweight dan sekitar 300 juta individu tergolong obese. ${ }^{2}$ Menurut data prevalensi di negara maju maupun berkembang obesitas umumnya terjadi pada wanita dibanding pria. The National Health and Nutrition Examination Survey tahun 2007-2008 pada penduduk dewasa Amerika Serikat menunjukkan prevalensi obesitas wanita lebih besar $(35,5 \%)$ dibanding pria $(32,2 \%){ }^{3}$ Data penelitian di Australia tahun 2003 menyatakan prevalensi obesitas wanita lebih tinggi $(34,1 \%)$ dibanding pria $(26,8 \%){ }^{4}$ Angka kejadian obesitas di Indonesia pada penduduk berusia 20 tahun ke atas berdasarkan data Demographic Health Surveys tahun 2000-2001 menyatakan obesitas pada wanita lebih besar $(4,5 \%$.) dibanding pria $(1,3 \%) .^{5}$ Berdasarkan data WHO tahun 2008 pada penduduk Indonesia usia 20 tahun ke atas menunjukkan prevalensi obesitas lebih tinggi pada wanita $(6,9 \%)$ dibanding pria $(2,5 \%){ }^{6}$

Dewasa ini obesitas mengalami pergeseran, awalnya obesitas cenderung dikaitkan dengan masyarakat perkotaan namun sekarang obesitas juga dialami oleh masyarakat pedesaan. Berdasarkan data Riskesdas tahun 2010 prevalensi wanita obese lebih tinggi di daerah perkotaan $(18,7 \%)$ dibanding daerah pedesaan $(12 \%){ }^{7}$ Begitu juga survei di 36 negara berkembang menyebutkan obesitas banyak terjadi di daerah urban $(51 \%)$ daripada rural (38\%), hal ini dikarenakan dikarenakan adanya kemudahan akses terhadap pangan dan transportasi seperti tersedianya makanan siap saji yang tinggi kalori dan alat transportasi yang sering menggunakan kendaraan bermotor. ${ }^{8}$ Selain itu juga terdapat beberapa faktor risiko obesitas lainnya meliputi usia, asupan makanan, aktivitas fisik, tingkat sosial ekonomi dan pengetahuan gizi.

Usia juga berkaitan dengan obesitas dimana peningkatan usia menyebabkan metabolisme tubuh menurun sehingga terjadi perubahan biologis yaitu penurunan fungsi otot dan peningkatan lemak tubuh. Penelitian di Malaysia menemukan bahwa obesitas kelompok umur 20-49 tahun lebih tinggi prevalensinya $(58,2 \%)$ dibandingkan kelompok umur 50-59 tahun $(45,6 \%){ }^{9}$

Perubahan pola makan dengan seringnya mengkonsumsi makanan dalam jumlah yang berlebihan baik karbohidrat, lemak dan protein juga dapat menyebabkan terjadinya obesitas. Data The Australian Food and Nutrition Monitoring Unit menunjukkan bahwa asupan energi penduduk Australia dewasa meningkat sekitar 3\%-4\%, hal ini dapat meningkatkan berat badan kira-kira 1 $\mathrm{kg} /$ tahun. $^{10}$

Aktivitas fisik juga merupakan penentu penting dalam peningkatan berat badan, karena kondisi yang inaktif dapat menimbulkan kejadian gizi lebih. Data FINRISK Studies menyimpulkan bahwa obesitas lebih berpotensi pada orang dengan aktivitas fisik ringan, misalnya pada mereka yang menghabiskan waktu luangnya hanya dengan membaca atau menonton televisi dan juga orang yang memilih menggunakan kendaraan bermotor dalam beraktivitas daripada berjalan kaki/bersepeda. ${ }^{11}$

Status sosial ekonomi juga mempengaruhi kejadian obesitas. Penelitian di Australia menunjukkan bahwa peningkatan pendapatan meningkatkan risiko obesitas, ${ }^{4}$ hal ini serupa dengan hasil penelitian di Missouri yang menjelaskan bahwa wanita yang berpenghasilan tinggi $(\geq \$ 9000)$ tergolong obese dibandingkan dengan yang berpenghasilan $<\$ 6000 .^{12}$

Pengetahuan gizi juga menjadi faktor yang berhubungan dengan masalah gizi seperti obesitas. Penelitian di Maastricht University yang meneliti tentang pengetahuan kaitannya dengan obesitas menunjukkan bahwa persentase jawaban yang benar pada tes pengetahuan meningkat dari $30 \%$ (pretest) menjadi $42 \%$ (posttest) setelah diberikan edukasi selama 1 bulan. ${ }^{13}$

Berdasarkan penjelasan di atas peneliti tertarik untuk menganalisis apakah pergeseran kejadian overweight antara di kota dan desa menyebabkan terjadinya pergeseran karakteristik (usia, asupan makanan, aktivitas fisik, tingkat sosial ekonomi dan pengetahuan gizi) di kedua tempat tinggal tersebut.

\section{METODA}

Penelitian dilaksanakan di Kelurahan Lamper Kidul Kecamatan Semarang Selatan (kota) dan Dukuh Sedayu Kelurahan Kalisegoro Kecamatan Gunungpati (desa). Ruang lingkup penelitian adalah penelitian bidang gizi masyarakat dan merupakan studi observasional dengan metode cross-sectional (belah lintang).

Populasi pada penelitian ini adalah wanita dewasa usia $20-40$ tahun. Berdasarkan perhitungan besar sampel menggunakan rumus rerata dua populasi didapatkan subjek minimal sebesar 27 subjek untuk masing-masing kelompok, 
tetapi pada penelitian ini didapatkan 30 subjek untuk masing-masing kelompok. Cara pengambilan subjek dilakukan dengan metode consecutive sampling dengan kriteria inklusi yaitu wanita berusia $20-40$ tahun dengan IMT $\geq 25,0$ $\mathrm{kg} / \mathrm{m}^{2}$, tidak sedang menjalani diet khusus, tidak merokok/mengkonsumsi alkohol.

Variabel independen adalah lingkungan tempat tinggal (desa dan kota). Variabel dependen adalah usia, asupan makanan (energi, karbohidrat, protein, lemak dan serat), aktivitas fisik, tingkat sosial ekonomi (pendapatan dan pendidikan) dan pengetahuan gizi.

Lingkungan tempat tinggal didefinisikan sebagai lokasi/wilayah pemukiman seseorang berdasarkan keadaan demografis yaitu desa dan kota.

Usia didefinisikan sebagai usia subjek dalam tahun berdasarkan tanggal lahir yang diketahui melalui identitas subjek dengan batasan usia $20-$ 40 tahun.

Asupan makanan terdiri dari asupan energi, asupan karbohidrat, asupan protein, asupan lemak dan asupan serat. Asupan energi didefinisikan sebagai asupan sumber energi dari makanan dan minuman yang dikonsumsi selama penelitian meliputi jenis makanan sumber energi, jumlah dan frekuensi yang diperoleh dengan kuesioner food frequency. Data jumlah asupan energi dibandingkan dengan kebutuhan energi sehari setiap individu, kemudian dikategorikan menjadi : defisit $(<70 \%)$, kurang $(\geq 70-99 \%)$, baik $(100-105 \%)$ dan lebih $(>105 \%)$.

Asupan karbohidrat didefinisikan sebagai asupan sumber karbohidrat dari makanan dan minuman yang dikonsumsi selama penelitian meliputi jenis makanan sumber karbohidrat, jumlah dan frekuensi yang diperoleh dengan kuesioner food frequency. Data jumlah asupan karbohidrat dibandingkan dengan kebutuhan karbohidrat sehari setiap individu, kemudian dikategorikan menjadi : kurang $(<80 \%)$, baik $(80-100 \%)$ dan lebih (> 100\%).

Asupan protein didefinisikan sebagai asupan sumber protein dari makanan dan minuman yang dikonsumsi selama penelitian meliputi jenis makanan sumber protein, jumlah dan frekuensi yang diperoleh dengan kuesioner food frequency. Data jumlah asupan protein dibandingkan dengan kebutuhan protein sehari setiap individu, kemudian dikategorikan menjadi : kurang $(<80 \%)$, baik (80$100 \%)$, lebih (> 100\%).

Asupan lemak didefinisikan sebagai asupan sumber lemak dari makanan dan minuman yang dikonsumsi selama penelitian meliputi jenis makanan sumber lemak, jumlah dan frekuensi yang diperoleh dengan kuesioner food frequency. Data jumlah asupan lemak dibandingkan dengan kebutuhan lemak sehari setiap individu, kemudian dikategorikan menjadi : kurang $(<80 \%)$, baik $(80$ $100 \%)$, lebih (> 100\%).

Asupan serat didefinisikan sebagai asupan sumber serat dari makanan dan minuman yang dikonsumsi selama penelitian meliputi jenis makanan sumber serat, jumlah dan frekuensi yang diperoleh dengan kuesioner food frequency. Data jumlah asupan serat dibandingkan dengan kebutuhan serat sehari setiap individu, kemudian dikategorikan menjadi : baik ( $\geq 25$ gram) dan kurang $(<25$ gram).

Aktivitas fisik didefinisikan sebagai rerata kegiatan fisik yang dilakukan responden yang diperoleh melalui dairy activity $3 \times 24$ jam meliputi aktivitas sehari-hari, sedentary lifestyle dan olahraga serta lamanya waktu untuk tiap kegiatan. Data yang diperoleh kemudian dihitung dengan mengkalikan berat badan, koefisien aktifitas fisik, dan menit yang digunakan dalam beraktifitas. Dikategorikan menjadi : ringan $(<2000 \mathrm{kkal})$, sedang (2000 - $2400 \mathrm{kkal})$ dan berat (> $2400 \mathrm{kkal})$.

Pendapatan didefinisikan sebagai jumlah uang yang diperoleh subjek selama 1 bulan yang berasal dari hasil kerjanya maupun pemberian dari anggota keluarga lainnya yang diketahui melalui kuesioner identitas subjek dan dikategorikan menjadi : $<1$ juta rupiah, $1-5$ juta rupiah dan $>5$ juta rupiah.

Pendidikan didefinisikan sebagai jumlah tahun tamat/selesai sekolah yang diperoleh subjek dari pendidikan formal yang diikuti, tahun yang berulang atau tinggal kelas tidak dihitung. Diketahui melalui kuesioner identitas subjek dan dikategorikan menjadi : SD, tamat SD, SMP, tamat SMP, SMA, tamat SMA, Diploma (D3), Sarjana (S1), Master (S2), Doktor (S3).

Pengetahuan gizi didefinisikan sebagai skor kemampuan responden menjawab pertanyaan dengan benar tentang zat gizi seimbang dan pola makan yang benar. Diukur menggunakan kuesioner pengetahuan gizi, jawaban benar $=1$ dan salah $=0$. Total skor pengetahuan yang diperoleh dibandingkan dengan total skor seharusnya dikalikan $100 \%$ dan dikategorikan menjadi : baik (> 80\% jawaban benar), cukup (60 - 80\% jawaban benar) dan kurang $(<60 \%$ jawaban benar).

Akses terhadap pangan didefinisikan sebagai jangkauan subjek untuk memperoleh dan 
mencukupi kebutuhan makanan sehari-hari meliputi tempat dan jarak yang ditempuh antara di kota dan desa, terdiri dari : pasar, warung/pedagang, swalayan/supermarket dan kebun/sawah milik sendiri yang dapat diketahui dari kuesioner identitas subjek.

Analisis data menggunakan program Statistic Package for the Social Science (SPSS) versi 13.00. Analisis univariat dilakukan untuk mendiskripsikan masing-masing variabel. Analisis bivariat menggunakan uji Independent t-Test untuk data berdistribusi normal (asupan energi, asupan karbohidrat, asupan protein, asupan lemak, aktivitas fisik dan pengetahuan gizi), sedangkan untuk data yang berdistribusi tidak normal (usia, asupan serat, pendapatan dan pendidikan) menggunakan uji Mann-Whitney.

\section{HASIL PENELITIAN \\ A. Karakteristik Subjek}

Berikut ini merupakan tabel karakteristik subjek yang meliputi usia subjek, status gizi dan status pernikahan.

Tabel 1. Karakteristik Subjek Berdasarkan Usia Subjek, Status Gizi dan Status Pernikahan

\begin{tabular}{lcccc}
\hline \multirow{2}{*}{ Variabel } & \multicolumn{2}{c}{ Desa } & \multicolumn{2}{c}{ Kota } \\
\cline { 2 - 5 } & n & \% & n & \% \\
\hline Usia Subjek & 6 & 20 & 10 & 33,3 \\
$20-29$ tahun & 24 & 80 & 20 & 66,7 \\
$30-40$ tahun & & & & \\
Status Gizi & 23 & 76,7 & 10 & 33,3 \\
Overweight & 7 & 23,3 & 20 & 66,7 \\
Obesitas & & & & \\
Status Pernikahan & 30 & 100 & 28 & 93,3 \\
Menikah & 0 & 0 & 2 & 6,7 \\
Belum Menikah & & & & \\
\hline
\end{tabular}

Rentang usia subjek pada masing-masing kelompok adalah 20 sampai 40 tahun. Frekuensi wanita dengan kelebihan berat badan di desa dan kota terbanyak berusia 30 sampai 40 tahun, namun proporsi di desa $(80 \%)$ lebih tinggi dibanding di kota $(66,7 \%)$. Nilai rerata usia wanita dengan kelebihan berat badan di desa adalah 35,2 tahun $\pm 5,3$, sedangkan di kota 32,5 tahun $\pm 5,1$. Terdapat perbedaan usia $(p=0,013)$ antara wanita dengan kelebihan berat badan di desa dan kota.

Kejadian obesitas lebih tinggi frekuensinya di kota $(66,7 \%)$ daripada di desa $(23,3 \%)$. Nilai rerata indeks massa tubuh wanita dengan kelebihan berat badan di desa adalah 28,9 $\mathrm{kg} / \mathrm{m}^{2} \pm 2,4$, sedangkan di kota $30,6 \mathrm{~kg} / \mathrm{m}^{2} \pm 3,7$.

Kelebihan berat badan di desa maupun di kota sesuai data yang diperoleh sebagian besar dialami oleh wanita yang sudah menikah, yaitu wanita dengan kelebihan berat badan di desa (100\%) dan di kota $(93,3 \%)$ telah menikah.

\section{B. Karakteristik Asupan Makanan}

Asupan energi wanita dengan kelebihan berat badan di desa dan kota tergolong berlebih, tetapi proporsi asupan energi wanita dengan kelebihan berat badan di kota $(90 \%)$ lebih tinggi dibandingkan di desa $(63,3 \%)$. Nilai rerata asupan energi wanita dengan kelebihan berat badan di kota lebih tinggi yaitu 2167,3 kkal $\pm 149,4$, sedangkan di desa 2063,2 kkal $\pm 182,9$. Terdapat perbedaan asupan energi ( $p$ $=0,019)$ antara wanita dengan kelebihan berat badan di desa dan kota. Berikut ini merupakan tabel nilai rerata asupan energi, karbohidrat, protein, lemak dan serat pada subjek di desa dan kota.

Tabel 2. Rerat Asupan Energi, Asupan Karbohidrat, Asupan Protein, Asupan Lemak dan Asupan Serat pada Subjek di Desa dan Kota

\begin{tabular}{lcc}
\hline \multirow{2}{*}{ Variabel } & \multicolumn{2}{c}{ rerata \pm SD } \\
\cline { 2 - 3 } & Desa & Kota \\
\hline Asupan energi (kkal) & $2063,2 \pm 182,9$ & $2167,3 \pm 149,4$ \\
Asupan karbohidrat (gram) & $262,3 \pm 13,3$ & $281,3 \pm 21,5$ \\
Asupan protein (gram) & $62,6 \pm 7,7$ & $81,6 \pm 10,4$ \\
Asupan lemak (gram) & $63,5 \pm 5,8$ & $76,7 \pm 10,9$ \\
\hline
\end{tabular}




\begin{tabular}{lcc}
\hline Asupan serat (gram) & $14,4 \pm 2,9$ & $12,6 \pm 3,6$ \\
\hline
\end{tabular}

Berikut ini merupakan tabel karakteristik asupan makanan subjek yang meliputi asupan energi, karbohidrat, protein, lemak dan serat.

Tabel 3. Karakteristik Asupan Makanan Berdasarkan Asupan Energi, Asupan Karbohidrat, Asupan Protein, Asupan Lemak dan Asupan Serat

\begin{tabular}{|c|c|c|c|c|}
\hline \multirow{2}{*}{ Variabel } & \multicolumn{2}{|c|}{ Desa } & \multicolumn{2}{|c|}{ Kota } \\
\hline & $\mathbf{n}$ & $\%$ & $\mathbf{n}$ & $\%$ \\
\hline \multicolumn{5}{|l|}{ Asupan Energi } \\
\hline Baik (100-105\%) & 11 & 36,7 & 3 & 10 \\
\hline Lebih (> 105\%) & 19 & 63,3 & 27 & 90 \\
\hline \multicolumn{5}{|l|}{ Asupan Karbohidrat } \\
\hline Baik (80-100\%) & 30 & 100 & 24 & 80 \\
\hline Lebih (> 100\%) & 0 & 0 & 6 & 20 \\
\hline \multicolumn{5}{|l|}{ Asupan Protein } \\
\hline Lebih (> 100\%) & 30 & 100 & 30 & 100 \\
\hline \multicolumn{5}{|l|}{ Asupan Lemak } \\
\hline Lebih (> 100\%) & 30 & 100 & 30 & 100 \\
\hline \multicolumn{5}{|l|}{ Asupan Serat } \\
\hline Kurang $(<25$ gram $)$ & 30 & 100 & 30 & 100 \\
\hline
\end{tabular}

Sebagian besar asupan karbohidrat wanita dengan kelebihan berat badan di desa dan kota tergolong baik, namun masih ada $20 \%$ subjek di kota yang memiliki asupan karbohidrat berlebih. Nilai rerata asupan karbohidrat wanita dengan kelebihan berat badan di kota lebih tinggi yaitu 281,3 gram $\pm 21,5$, sedangkan di desa 262,3 gram $\pm 13,3$. Terdapat perbedaan asupan karbohidrat $(\mathrm{p}=0,000)$ antara wanita dengan kelebihan berat badan di desa dan kota.

Asupan protein dan lemak wanita dengan kelebihan berat badan di desa dan kota tergolong berlebih (100\%), namun rerata asupan protein dan lemak wanita dengan kelebihan berat badan di kota lebih tinggi dibandingkan di desa. Rerata asupan protein wanita dengan kelebihan berat badan di kota adalah 81,6 gram $\pm 10,4$, sedangkan di desa 62,6 gram $\pm 7,7$. Rerata asupan lemak wanita dengan kelebihan berat badan di kota adalah 76,7 gram $\pm 10,9$, sedangkan di desa 63,5 gram $\pm 5,8$. Terdapat perbedaan asupan protein $(\mathrm{p}$ $=0,000$ ) antara wanita dengan kelebihan berat badan di desa dan kota. Terdapat perbedaan asupan lemak $(p=0,000)$ antara wanita dengan kelebihan berat badan di desa dan kota.
Hasil penelitian menunjukkan bahwa $100 \%$ wanita dengan kelebihan berat badan di desa dan kota memiliki asupan serat yang kurang, tetapi nilai rerata asupan serat wanita dengan kelebihan berat badan di desa lebih tinggi yaitu 14,4 gram $\pm 2,9$, sedangkan di kota 12,6 gram $\pm 3,6$. Terdapat perbedaan asupan serat $(\mathrm{p}=0,014)$ antara wanita dengan kelebihan berat badan di desa dan kota.

\section{Karakteristik Aktivitas Fisik}

Kelebihan berat badan tidak hanya dialami oleh subjek dengan tingkat aktivitas ringan saja, tetapi juga terjadi pada subjek dengan tingkat aktivitas berat. Aktivitas fisik sebagian besar wanita dengan kelebihan berat badan di desa $(60 \%)$ tergolong berat, sedangkan di kota $(33,3 \%)$ tergolong ringan. Nilai rerata aktivitas fisik wanita dengan kelebihan berat badan di desa lebih tinggi yaitu 2515,6 kkal $\pm 235,7$, sedangkan di kota $2237,4 \mathrm{kkal} \pm 285,5$. Terdapat perbedaan aktivitas fisik $(\mathrm{p}=0,000)$ antara wanita dengan kelebihan berat badan di desa dan kota. Berikut ini merupakan tabel karakteristik aktivitas fisik subjek yang meliputi aktivitas fisik, kebiasaan olahraga, durasi menonton televisi, dan kegiatan sedentary lifestyle. 
Tabel 4. Karakteristik Aktivitas Fisik Berdasarkan Aktivitas Fisik, Kebiasaan Olahraga, Durasi Menonton Televisi, dan Kegiatan Sedentary Lifestyle

\begin{tabular}{lcccc}
\hline \multirow{2}{*}{ Variabel } & \multicolumn{2}{c}{ Desa } & \multicolumn{2}{c}{ Kota } \\
\cline { 2 - 5 } & n & \% & n & \% \\
\hline Aktivitas Fisik & 0 & 0 & 10 & 33,3 \\
Ringan (<2000 kkal) & 12 & 40 & 13 & 43,3 \\
Sedang (2000 -2400 kkal) & 18 & 60 & 7 & 23,3 \\
Berat (> 2400 kkal) & & & & \\
Kebiasaan Olahraga & 0 & 0 & 9 & 30 \\
Ya & 30 & 100 & 21 & 70 \\
Tidak & & & & \\
Durasi Menonton Televisi & 30 & 100 & 14 & 46,7 \\
2-5 jam/hari & 0 & 0 & 16 & 53,3 \\
6-8 jam/hari & & & & \\
Kegiatan Sedentary Lifestyle & 17 & 56,7 & 8 & 26,7 \\
Tiduran/bermalas-malasan & 13 & 43,3 & 16 & 53,3 \\
Menonton televisi & 0 & 0 & 3 & 10 \\
Membaca & & & & \\
\hline
\end{tabular}

Sebagian besar wanita dengan kelebihan berat badan di desa maupun di kota tidak pernah berolahraga. Seluruh wanita dengan kelebihan berat badan di desa (100\%) tidak berolahraga, sedangkan di kota hanya $30 \%$ yang berolahraga.

Wanita dengan kelebihan berat badan di desa dan kota memiliki kebiasaan menoton televisi lebih dari satu jam per hari. Seluruh wanita dengan kelebihan berat badan di desa (100\%) menghabiskan 2-5 jam waktunya untuk menonton televisi setiap hari, sedangkan wanita dengan kelebihan berat badan di kota $(53,3 \%)$ menonton televisi selama 6-8 jam per hari.

Wanita dengan kelebihan berat badan di desa dan kota menghabiskan waktu luang mereka dengan melakukan gaya hidup sedentari seperti menonton televisi, tiduran/bermalas-malasan dan membaca. Wanita dengan kelebihan berat badan di desa $(56,7 \%)$ menghabiskan waktu luang mereka dengan tiduran/bermalas-malasan, sedangkan di kota $(53,3 \%)$ subjeknya menonton televisi saat waktu luang.

\section{Karakteristik Sosial Ekonomi}

Tingkat pendidikan wanita dengan kelebihan berat badan di desa sebagian besar telah tamat SD, sedangkan di kota lebih dari separuhnya berpendidikan tamat SMA. Kelebihan berat badan tidak hanya terjadi pada subjek dengan tingkat pendidikan rendah, tapi juga dapat terjadi pada subjek yang berpendidikan tinggi. Wanita dengan kelebihan berat badan di desa sebagian besar terjadi pada tingkat pendidikan rendah yaitu sekolah dasar $(66,7 \%)$. Sedangkan di kota, kelebihan berat badan dialami oleh subjek yang berpendidikan sekolah menengah atas $(73,3 \%)$. Nilai rerata tahun menyelesaikan sekolah wanita dengan kelebihan berat badan di desa lebih rendah yaitu 8 tahun $\pm 2,9$, sedangkan di kota 12,9 tahun $\pm 1,6$. Terdapat perbedaan pendidikan $(\mathrm{p}=0,000)$ antara wanita dengan kelebihan berat badan di desa dan kota. Berikut ini merupakan tabel karakteristik sosial ekonomi subjek yang meliputi pendidikan, pekerjaan dan pendapatan.

Tabel 5. Karakteristik Sosial Ekonomi Berdasarkan Pendidikan, Pekerjaan dan Pendapatan

\begin{tabular}{lcccc}
\hline \multirow{2}{*}{ Variabel } & \multicolumn{2}{c}{ Desa } & \multicolumn{2}{c}{ Kota } \\
\cline { 2 - 6 } & n & \% & n & \% \\
\hline Pendidikan & 20 & 66,7 & 0 & 0 \\
Tamat SD & 10 & 33,3 & 22 & 73,3 \\
Tamat SMA & 0 & 0 & 4 & 13,3 \\
Diploma & 0 & 0 & 4 & 13,3 \\
Sarjana & & & & \\
Pekerjaan & 9 & 30 & 11 & 36,7 \\
Ibu Rumah Tangga & & & &
\end{tabular}




\begin{tabular}{lcccc}
\hline Karyawan Swasta & 5 & 16,7 & 11 & 36,7 \\
Wiraswasta & 0 & 0 & 8 & 26,7 \\
Petani & 8 & 26,7 & 0 & 0 \\
Buruh & 8 & 26,7 & 0 & 0 \\
Pendapatan & & & & \\
< Rp. 1 juta & 5 & 16,7 & 0 & 0 \\
Rp. $1-5$ juta & 25 & 83,3 & 28 & 93,3 \\
> Rp. 5 juta & 0 & 0 & 2 & 6,7 \\
\hline
\end{tabular}

Kelebihan berat badan di kota sebagian besar terjadi pada ibu rumah tangga dan karyawan swasta, sedangkan di desa dialami oleh ibu rumah tangga, buruh dan petani. Selain itu, wanita dengan kelebihan berat badan di desa juga ada yang bekerja sebagai karyawan swasta, sedangkan di kota ada juga yang berwiraswasta.

Kelebihan berat badan tidak hanya terjadi pada subjek dengan pendapatan tinggi (> Rp. 5 juta), namun juga dialami oleh subjek yang berpendapatan rendah (<Rp. 1 juta). Sebesar $16,7 \%$ subjek di desa berpenghasilan kurang dari satu juta rupiah, sedangkan $6,7 \%$ subjek di kota berpenghasilan lebih dari lima juta rupiah. Nilai rerata pendapatan wanita dengan kelebihan berat badan di desa lebih rendah yaitu 1.430 .000 rupiah $\pm 440923,8$, sedangkan di kota 2.961.667 rupiah $\pm 1573743,8$. Terdapat perbedaan pendapatan $(\mathrm{p}=0,000)$ antara wanita dengan kelebihan berat badan di desa dan kota.

\section{E. Karakteristik Pengetahuan Gizi}

Berikut ini merupakan tabel karakteristik pengetahuan gizi subjek.

Tabel 6. Karakteristik Pengetahuan Gizi

\begin{tabular}{lcccc}
\hline \multirow{2}{*}{ Variabel } & \multicolumn{2}{c}{ Desa } & \multicolumn{2}{c}{ Kota } \\
\cline { 2 - 5 } & n & \% & n & \% \\
\hline Pengetahuan Gizi & 18 & 60 & 0 & 0 \\
Kurang $(<60 \%)$ & 10 & 33,3 & 21 & 70 \\
Cukup $(60-80 \%)$ & 2 & 6,7 & 9 & 30 \\
Baik $(>80 \%)$ & & & &
\end{tabular}

Kelebihan berat badan tidak hanya dialami subjek dengan tingkat pengetahuan kurang, namun juga dapat terjadi pada subjek yang berpengetahuan baik. Wanita dengan kelebihan berat badan di desa (60\%) berpengetahuan kurang, sedangkan di kota sebagian besar (70\%) berpengetahuan cukup. Nilai rerata skor pengetahuan gizi wanita dengan kelebihan berat badan di desa lebih rendah yaitu $59,1 \% \pm 13,1$, sedangkan di kota 72,8\% $\pm 10,2$. Terdapat perbedaan pengetahuan gizi $(\mathrm{p}=0,000)$ antara wanita dengan kelebihan berat badan di desa dan kota.

\section{F. Karakteristik Akses Pangan}

Wanita dengan kelebihan berat badan di desa $(60 \%)$ memperoleh sumber bahan pangan mereka dari kebun/sawah, sedangkan di kota $(66,7 \%)$ mendapatkan sumber bahan pangan di pasar. Lokasi tempat tinggal wanita dengan kelebihan berat badan di kota hanya berjarak 1500 meter dari pasar sehingga mereka lebih sering berbelanja di pasar. Wanita dengan kelebihan berat badan di desa yang tidak memiliki kebun/sawah lebih memilih berbelanja di warung/pedagang, mereka enggan berbelanja di pasar karena jaraknya terlalu jauh $( \pm 5 \mathrm{~km})$. Berikut ini merupakan tabel karakteristik akses pangan subjek yang meliputi tempat memperoleh bahan pangan dan kebiasaan membeli makanan siap saji.

Tabel 7. Karakteristik Akses Pangan Berdasarkan Tempat Memperoleh Bahan Pangan dan Kebiasaan Membeli Makanan Siap Saji

\begin{tabular}{|c|c|c|c|c|c|}
\hline \multirow{2}{*}{\multicolumn{2}{|c|}{ Variabel }} & \multicolumn{2}{|c|}{ Desa } & \multicolumn{2}{|c|}{ Kota } \\
\hline & & $\mathbf{n}$ & $\%$ & $\mathbf{N}$ & $\%$ \\
\hline $\begin{array}{l}\text { Tempat } \\
\text { Pangan }\end{array}$ & Memperoleh Sumber & 0 & 0 & 20 & 66,7 \\
\hline
\end{tabular}




\begin{tabular}{lcccc}
\hline Pasar & 12 & 40 & 10 & 33,3 \\
Warung/pedagang & 18 & 60 & 0 & 0 \\
Kebun/sawah & & & & \\
Kebiasaan Membeli Makanan Siap Saji & 11 & 36,7 & 25 & 83,3 \\
Ya & 19 & 63,3 & 5 & 16,7 \\
Tidak & & & & \\
\hline
\end{tabular}

Wanita dengan kelebihan berat badan di desa $(36,7 \%)$ dan kota $(83,3 \%)$ sering mengkonsumsi makanan siap saji per bulan. Makanan siap saji yang sering dikonsumsi wanita dengan kelebihan berat badan di kota seperti fried chicken, burger, pizza, bakso, mi ayam, batagor, siomay dan masakan warteg. Sedangkan makanan siap saji yang sering dikonsumsi di desa seperti bakso, mi ayam, batagor dan siomay.

\section{PEMBAHASAN}

\section{A. Karakteristik Subjek}

Subjek pada penelitian ini adalah wanita dewasa dengan rentang usia antara 20 sampai 40 tahun. Frekuensi wanita dengan kelebihan berat badan terbanyak berusia 30 sampai 40 tahun, namun proporsi di desa $(80 \%)$ lebih tinggi dibanding di kota $(66,7 \%)$. Terdapat perbedaan usia $(\mathrm{p}=0,013)$ antara wanita dengan kelebihan berat badan di desa dan kota. Hal ini disebabkan karena tingkat metabolisme tubuh menurun sehingga terjadi perubahan biologis yaitu penurunan fungsi otot dan peningkatan lemak tubuh. Lemak tubuh mulai menumpuk pada usia 30 tahun, karena kesibukan kerja sehingga menyebabkan kurangnya waktu untuk berolahraga. Jika seseorang tidak mengontrol pola makan dan mempunyai gaya hidup sedentari maka akan berisiko mengalami kegemukan. ${ }^{14}$

Kejadian obesitas lebih tinggi frekuensinya di kota $(66,7 \%)$ daripada di desa $(23,3 \%)$. Penelitian yang sama di 36 negara berkembang menyebutkan bahwa prevalensi obesitas banyak terjadi di daerah urban (51\%) daripada rural (38\%), tempat tinggal secara positif berhubungan dengan overweight dan obesitas karena di perkotaan banyak ditemukan kemudahan akses terhadap pangan dan transportasi seperti tersedianya makanan siap saji yang tinggi kalori dan alat transportasi yang sering menggunakan kendaraan bermotor. ${ }^{8}$

Hal lain yang ditemukan pada penelitian ini adalah wanita dengan kelebihan berat badan di desa maupun di kota sebagian besar dialami oleh wanita yang sudah menikah, yaitu wanita dengan kelebihan berat badan di desa $(100 \%)$ dan di kota $(93,3 \%)$ telah menikah. Sebuah studi cross-sectional menunjukkan bahwa status pernikahan secara signifikan berhubungan dengan peningkatan berat badan selama 2 tahun pernikahan, hal ini disebabkan adanya pengaruh peningkatan nafsu makan yang berlebihan sehingga menyebabkan subjek makan berlebihan sehingga lepas kontrol terhadap pengaturan berat badan. $^{15}$

\section{B. Karakteristik Asupan Makanan}

Kelebihan asupan makanan juga dapat menimbulkan kelebihan berat badan. Asupan energi wanita dengan kelebihan berat badan di desa dan kota tergolong berlebih, tetapi asupan energi wanita dengan kelebihan berat badan di kota (90\%) lebih tinggi dibandingkan di desa (63.3\%). Terdapat perbedaan asupan energi $(p=0,019)$ antara wanita dengan kelebihan berat badan di desa dan kota. Walaupun energi bukan merupakan zat gizi, tetapi energi selalu berkaitan dengan karbohidrat, lemak dan protein. Energi merupakan hasil dari metabolisme karbohidrat, lemak dan protein. Peningkatan jumlah asupan energi diatas angka kecukupan gizi yang dianjurkan dapat mempengaruhi perkembangan obesitas. ${ }^{16}$

Asupan karbohidrat wanita dengan kelebihan berat badan di desa dan kota tergolong baik, namun masih ada $20 \%$ subjek pada kelompok perkotaan yang memiliki asupan karbohidrat berlebih. Terdapat perbedaan asupan karbohidrat $(p=0,000)$ antara wanita dengan kelebihan berat badan di desa dan kota. Menurut rekomendasi WHO bahwa asupan karbohidrat yang dianjurkan adalah $55 \%-75 \%$ dari total energi. ${ }^{17}$ Konsumsi karbohidrat secara berlebihan tanpa disertai pengeluaran energi yang seimbang menyebabkan glukosa banyak tertimbun dan apabila kondisi ini berlangsung lama dapat mengakibatkan terjadinya kegemukan. ${ }^{16}$

Hasil analisis asupan makanan yang lain menunjukkan bahwa $100 \%$ wanita 
dengan kelebihan berat badan pada kedua kelompok memiliki asupan protein yang berlebihan, namun nilai rerata asupan protein wanita dengan kelebihan berat badan di kota lebih tinggi yaitu 81,57 gram, sedangkan di desa 62,60 gram. Terdapat perbedaan asupan protein $(\mathrm{p}=0,000)$ antara wanita dengan kelebihan berat badan di desa dan kota. Konsumsi protein yang berlebihan tidak menguntungkan bagi tubuh karena makanan yang tinggi protein biasanya tinggi lemak, misalnya sumber protein hewani seperti daging merah, kuning telur, keju, susu full cream mengandung lemak dalam jumlah besar sehingga dapat menimbulkan peningkatan kadar lemak dan kolesterol, dan apabila dikonsumsi dalam jangka panjang menyebabkan kegemukan. ${ }^{16}$

Hasil penelitian karakteristik asupan makanan lainnya menunjukkan bahwa seluruh wanita dengan kelebihan berat badan $(100 \%)$ di desa dan kota memiliki asupan lemak berlebih, namun nilai rerata asupan lemak wanita dengan kelebihan berat badan di kota lebih tinggi yaitu 76,73 gram, sedangkan di desa 63,47 gram. Terdapat perbedaan asupan lemak $(\mathrm{p}=0,000)$ antara wanita dengan kelebihan berat badan di desa dan kota. Anjuran konsumsi lemak tidak boleh lebih dari $25 \%$ dari kebutuhan energi sehari-hari. ${ }^{18}$ Proporsi asupan lemak yang berlebihan bisa menjadi faktor risiko bagi perkembangan obesitas.

Perbedaan asupan makanan antara dua kelompok subjek disebabkan karena wanita dengan kelebihan berat badan di kota lokasinya berada di tengah kota sehingga membuat subjek lebih mudah mengakses sumber makanan misalnya makanan siap saji. Makanan siap saji umumnya mengandung tinggi kalori, lemak jenuh, kolesterol, dan natrium tetapi kandungan serat, kalsium, besi, riboflavin, asam folat, vitamin $\mathrm{A}$ dan $\mathrm{C}$ sangat sedikit sehingga memiliki kandungan gizi yang tidak seimbang. ${ }^{19}$ Kegemaran dan kebiasaan konsumsi makanan siap saji dapat mengawali terjadinya penyakit degeneratif, salah satunya adalah obesitas.

Hal lain yang ditemukan pada penelitian ini menunjukkan bahwa 100\% wanita dengan kelebihan berat badan di desa dan kota memiliki asupan serat yang kurang, namun nilai rerata asupan serat wanita dengan kelebihan berat badan di desa lebih tinggi yaitu 14,46 gram sedangkan di kota 12,63 gram. Terdapat perbedaan asupan serat $(\mathrm{p}=$ 0,014 ) antara wanita dengan kelebihan berat badan di desa dan kota. Meskipun asupan serat wanita dengan kelebihan berat badan di desa lebih tinggi, namun kedua kelompok subjek memiliki asupan serat yang kurang dari kebutuhan serat per hari. Anjuran asupan serat dikatakan baik jika $\geq 25$ gram dan kurang jika $<25$ gram. $^{20}$

Menurut WHO asupan serat berhubungan dengan pengaturan berat badan dan pencegahan obesitas, orang dengan konsumsi serat tinggi dapat mengeluarkan lebih banyak asam empedu sehingga mengeluarkan lebih banyak lemak dan sterol dari feces. Hal tersebut berarti serat dapat mencegah penyerapan asam empedu, lemak dan kolesterol sehingga dapat mencegah terjadinya overweight dan obesitas. ${ }^{21}$ Selain itu makanan yang tinggi serat dapat menurunkan respon insulin sehingga meningkatkan rasa kenyang dan munurunkan rasa lapar. ${ }^{22}$

\section{Karakteristik Aktivitas Fisik}

Kelebihan berat badan tidak hanya terjadi pada subjek dengan tingkat aktivitas ringan saja, tetapi juga dapat terjadi pada subjek dengan tingkat aktivitas berat. Aktivitas fisik sebagian besar wanita dengan kelebihan berat badan di desa $(60 \%)$ tergolong berat, sedangkan di kota $(33,3 \%)$ tergolong pada kategori aktivitas fisik ringan. Terdapat perbedaan aktivitas fisik $(\mathrm{p}=0,000)$ antara wanita dengan kelebihan berat badan di desa dan kota. Pengeluaran energi untuk aktivitas pada wanita dengan kelebihan berat badan di desa lebih besar sedangkan di kota tergolong ringan, karena aktivitas fisik subjek di desa tergolong berat seperti bercocok tanam/bertani, selama \pm 6 jam mereka bekerja di ladang/sawah dan masih ditambah dengan pekerjaan rumah tangga seperti menyapu lantai, mengepel lantai, menyetrika baju dan mencuci pakaian. Sedangkan wanita dengan kelebihan berat badan di kota hanya melakukan pekerjaan rumah tangga saja selama \pm 3 jam.

Gaya hidup sedentari wanita dengan kelebihan berat badan di kota lebih tinggi, hal ini terbukti dari lamanya menonton televisi. Berdasarkan penelitian diketahui bahwa wanita dengan kelebihan berat badan di kota $(53,3 \%)$ menghabiskan 6-8 jam waktunya 
untuk menonton televisi setiap harinya, sedangkan di desa $(100 \%)$ menonton televisi 2-5 jam per hari. Kegiatan sedentari yang dilakukan subjek pada masing-masing kelompok adalah menonton televisi dan tiduran/bermalas-malasan. Wanita dengan kelebihan berat badan di kota membutuhkan waktu 6-8 jam sedangkan di desa 2-5 jam untuk melakukan kegiatan waktu luang mereka. Tiduran/bermalas-malasan dan menonton televisi merupakan contoh gaya hidup sedentari yang dapat mengurangi pengeluaran energi untuk aktivitas sehingga memperburuk status gizi.

Karakteristik kebiasaan olahraga pada penelitian ini ditemukan bahwa seluruh wanita dengan kelebihan berat badan di desa tidak pernah berolahraga, sedangkan $30 \%$ wanita dengan kelebihan berat badan di kota rutin berolahraga. Mereka rutin berolahraga 15 kali per minggu dengan durasi 1-5 jam. Frekuensi berolahraga atau latihan fisik 3 kali seminggu selama 30 menit secara teratur dapat menurunkan lemak pada daerah perut dan pinggul dan dapat mengontrol berat badan, serta dapat mengurangi penyakit kardiovaskuler, stroke dan kanker. ${ }^{23}$ Rendahnya intensitas untuk berolahraga inilah yang menjadi salah satu pemicu kejadian obesitas.

\section{Karakteristik Sosial Ekonomi}

Kelebihan berat badan tidak hanya terjadi pada subjek dengan tingkat pendidikan rendah, tapi juga dialami subjek yang berpendidikan tinggi. Kelebihan berat badan di desa sebagian besar terjadi pada tingkat pendidikan rendah yaitu sekolah dasar $(66,7 \%)$. Sedangkan di kota, kelebihan berat badan dialami oleh subjek yang berpendidikan sekolah menengah atas $(73,3 \%)$. Terdapat perbedaan pendidikan $(p=0,000)$ antara wanita dengan kelebihan berat badan di desa dan kota. Umumnya semakin tinggi pendidikan seseorang maka pekerjaanya semakin baik, maka tingkat pendapatan pun relatif lebih tinggi sehingga akan mempengaruhi gaya hidup akibat peningkatan kesejahteraan dan pada akhirnya akan mempengaruhi pola makan. Dimana pada sebagian orang beranggapan bahwa kelebihan berat badan berhubungan dengan kesejahteraan dan kemakmuran. ${ }^{24}$

Berdasarkan hasil penelitian, kelebihan berat badan di kota sebagian besar terjadi pada ibu rumah tangga dan karyawan swasta, sedangkan di desa dialami oleh ibu rumah tangga, buruh dan petani. Selain itu, wanita dengan kelebihan berat badan di desa juga ada yang bekerja sebagai karyawan swasta, sedangkan di kota berwiraswasta.

Pendapatan memiliki peranan penting dalam memenuhi kebutuhan makanan yang diperlukan oleh tubuh. Kelebihan berat badan tidak hanya terjadi pada subjek dengan pendapatan tinggi (> Rp. 5 juta), namun juga dialami oleh subjek yang mempunyai pendapatan rendah (< Rp. 1 juta). Sebesar $16,7 \%$ wanita dengan kelebihan berat badan di desa berpenghasilan kurang dari satu juta rupiah, sedangkan $6,7 \%$ wanita dengan kelebihan berat badan di kota berpenghasilan lebih dari lima juta rupiah. Terdapat perbedaan pendapatan $\quad(p=0,000)$ antara wanita dengan kelebihan berat badan di desa dan kota. Pendapatan yang tinggi biasanya mendukung seseorang untuk membeli bahan makanan dalam jumlah yang lebih dari cukup serta cenderung memilih makan siap saji yang lebih mudah dan praktis. Pendapatan yang tinggi dan pola makan yang berlebihan dapat menimbulkan penimbunan lemak tubuh, dimana lemak tubuh merupakan cerminan terjadinya overweight dan obesitas. ${ }^{25}$

E. Karakteristik Pengetahuan Gizi

Kelebihan berat badan tidak hanya terjadi pada subjek dengan tingkat pengetahuan yang kurang, namun juga dapat terjadi pada subjek yang berpengetahuan baik. Wanita dengan kelebihan berat badan di desa yang berpengetahuan kurang proporsinya lebih banyak (60\%), sedangkan di kota $(70 \%)$ berpengetahuan cukup. Terdapat perbedaan pengetahuan gizi $(p=0,000)$ antara wanita dengan kelebihan berat badan di desa dan kota. Pengetahuan gizi yang tidak mendukung tingkat kecukupan zat gizi dapat disebabkan karena kurang mampunya responden dalam menerjemahkan pengetahuan gizi yang dimilikinya dalam bentuk makanan sehari-hari sehingga dapat menyebabkan terjadinya gizi lebih. ${ }^{25}$

\section{F. Karakteristik Akses Pangan}

Berdasarkan hasil penelitian wanita dengan kelebihan berat badan di kota memperoleh sumber bahan pangan di pasar $(66,7 \%)$, sedangkan wanita dengan kelebihan berat badan di desa memperoleh sumber bahan pangan mereka di kebun/sawah (60\%). 
Lokasi tempat tinggal subjek kelompok kota yang dekat dengan pasar (1-500 meter) sehingga memudahkan subjek untuk mencari sumber bahan pangan dengan membelinya di pasar. Sedangkan subjek pada kelompok desa yang sebagian besar subjeknya bercocok tanam sehingga mereka memperoleh sumber bahan pangan di kebun/sawah. Subjek kelompok desa yang tidak bercocok tanam memperoleh sumber bahan pangan dari warung/pedagang, mereka enggan berbelanja ke pasar karena jaraknya terlalu jauh $( \pm 5 \mathrm{~km})$.

Dewasa ini masyarakat menginginkan segala sesuatu yang praktis, sehingga mereka cenderung memilih makan makanan siap saji yang tinggi kalori. Hasil penelitian menunjukkan wanita dengan kelebihan berat badan di desa (36,7\%) mengkonsumsi makanan siap saji per bulan, sedangkan wanita dengan kelebihan berat badan di kota $(83,3 \%)$ sering mengkonsumsi makanan siap saji per bulan. Makanan siap saji yang sering dikonsumsi subjek di kota seperti burger, pizza, spaghetti, fried chicken, bakso, batagor, siomay dan masakan warteg. Sedangkan makan siap saji yang sering dikonsumsi subjek di desa seperti bakso, batagor dan siomay. Perbedaan konsumsi makanan siap saji kedua kelompok dikarenakan letak lokasi kelompok kota yang berada di tengah kota membuat subjek lebih mudah mengakses makanan siap saji karena lokasi untuk mendapatkan makanan siap saji hanya berjarak 1-500 meter. Makanan siap saji cenderung tinggi energi namun rendah serat. ${ }^{1}$ Penyimpangan pola makan tersebut dapat menimbulkan penimbunan lemak tubuh, dimana lemak tubuh merupakan cerminan terjadinya overweight dan obesitas.

\section{SIMPULAN}

Prevalensi obesitas di kota lebih tinggi dibandingkan di desa. Pergeseran kejadian obesitas yang tidak hanya terjadi di kota namun juga di desa ternyata mempengaruhi perbedaan karakteristik pada wanita dengan kelebihan berat badan antara di desa dan kota meliputi usia, asupan energi, asupan karbohidrat, asupan protein, asupan lemak, asupan serat, aktivitas fisik, pendapatan, pendidikan dan pengetahuan gizi. Wanita dengan kelebihan berat badan di desa dan kota sebagian besar berusia 30-40 tahun, namun proporsinya lebih tinggi di desa dibandingkan di kota. Asupan energi, karbohidrat, protein dan lemak pada kedua kelompok tergolong berlebih, namun rerata asupan energi, karbohidrat, protein dan lemak di kota lebih tinggi dibandingkan di desa. Sedangkan asupan serat pada kedua kelompok tergolong kurang, namun rerata asupan serat di desa lebih tinggi dibandingkan di kota. Kelebihan berat badan tidak hanya terjadi pada wanita dengan aktivitas ringan saja, namun juga terjadi pada wanita yang memiliki aktivitas berat. Umunya kelebihan berat badan terjadi pada wanita dengan pendapatan tinggi, namun ternyata kelebihan berat badan juga dialami oleh wanita yang berpendapatan rendah. Kelebihan berat badan biasanya berkaitan dengan pendidikan yang rendah, akan tetapi wanita yang memiliki pendidikan tinggi pun juga bisa mengalami kelebihan berat badan. Kelebihan berat badan biasanya dikaitkan dengan pengetahuan gizi yang rendah, tapi wanita dengan pengetahuan gizi baik pun juga bisa mengalami kelebihan berat badan.

\section{SARAN}

Perlu adanya edukasi gizi pada wanita dengan kelebihan berat badan di desa dan kota. Melalui PKK setempat dilaksanakan penyuluhan gizi tentang kelebihan berat badan dan pola hidup sehat meliputi pengaturan berat badan, pengaturan pola makan serta peningkatan aktivitas fisik sehingga dapat terbentuk sikap dan praktek yang benar terhadap gaya hidup sehat sehari-hari.

\section{DAFTAR PUSTAKA}

1. Hadi H. Beban Ganda Masalah Gizi dan Implikasinya Terhadap Kebijakan Pembangunan Masyarakat. Yogyakarta. 2005.

2. World Health Organization. Obesity and overweight: programmes and project of global strategy on diet, physical activity and health. Geneva, Switzerland: WHO Document Production Services. 2010.

3. Flegal KM, Carroll MD, Ogden CL, Curtin LR. Prevalence and trends in obesity among US adults, 1999-2008. JAMA 2010;303(3):235-241.

4. Cameron AJ, Welborn TA, Zimmet PZ, Dunstan DW, Owen N, Salmon J et al. Overweight and obesity in Australia: The 1999-2000 Australian Diabetes, obesity and lifestyle study (AusDiab). MJA 2003;178:427-432.

5. International Association for The Study of Obesity. Global Prevalence of Adult Obesity. London. 2011.

6. World Health Organization. Indonesia: Health Profile. 2008. 
7. Riset Kesehatan Dasar (Riskesdas) 2010. Laporan Hasil Riset Kesehatan Dasar (Riskesdas) 2010. Jakarta: Badan Litbangkes, Depkes RI, 2010.

8. Mendez MA, Monteiro CA, Popkin BM. Overweight exceeds underweight among women in most developing countries. Am J Clin Nutr 2005;81:714-21.

9. Sidik SM, Rampal L. The prevalence and factor associated with obesity among adult women in Selangor, Malaysia. Asia Pasific Family Medcine 2009;8:2.

10. Cook T, Rutishauser IHE, Seelig M. Comparable data on food and nutrient intake and physical measurements from the 1983, 1985 and 1995 National Nutrition Surveys. Canberra: Commonwealth Department of Health and Aged Care, 2001.

11. Lahti-Koski M, Pietinen P, Heliovaara M, Vartiainen E. Assosiation of body mass index and obesity with physical activity, food choices, alcohol intake, and smoking in the 1982-1997 FINRISK Studies. Am J Clin Nutr 2002;75:80917.

12. Kohrs MB, Wang LL, Eklund D, Paulsen B, O'neal R. The association of obesity with sosioeconomic factors in Missouri. Am J Clin Nutr 1999;32:2120-2128.

13. Maiburg BHJ, Rethans JJE, Schuwirth LWT, Mathus-Vliegen LMH, van Ree JW. Controlled trial of effect of computer-based nutrition course on knowledge and practise of general practitioner trainees. Am J Clin Nutr 2003;77:1019S-24S.

14. Purwati S, dkk. Perencanaan Menu Untuk Penderita Kegemukan. Cetakan 7. Penebar Swadaya. Jakarta. 2005.

15. Jeffery RW, Rick AM. Cross-Sectional and Longitudinal Associations between Body Mass Index and Marriage-Related Factors. Obesity Research 2002; 10(8):809-815.

16. Almatsier S. Prinsip Dasar Ilmu Gizi. PT Gramedia Pustaka Utama. Jakarta. 2001.

17. Treacy J. Obesity. The Report of the National Taskforce on Obesity. Irlandia. 2005.

18. PUGS. Direktorat Bina Kesehatan Masyarakat. Direktorat Gizi Departemen Kesehatan RI. Jakarta. 2002.

19. Arisman. Gizi Dalam Daur Kehidupan. Jakarta: Penerbit Buku Kedokteran EGC; 2004. hal.65-66.

20. Hardinsyah TV. Angka Kecukupan Energi, Protein, Lemak dan Serat Makanan. Widyakarya Nasional Pangan dan Gizi VIII. Jakarta. 2004.

21. Winarno, F.G. Kimia Pangan dan Gizi. PT Gramedia Pustaka Utama. Jakarta. 1991.

22. Newby PK, Muller D, Hallfrisch J et al. Dietary patterns and changes in body mass index and waist circumference in adults. Am J Clin Nutr 2003;77:1417-25.

23. Eleanor S. Body composition, energy and physical activity. Mosby. 1994.
24. Soerjodibroto, Walujo. Asia Pasific Menu Pattern in Relation to Lipid Abnormalities: an Indonesia Perspective. Medical Journal of Indonesia 2004; no.13 pp.252-7.

25. Apriadji. Gizi Keluarga. Penebar Swadaya. Jakarta. 1996. 